\title{
IAMJ
}

INTERNATIONAL

AYURVEDIC

MEDICAL JOURNAL

\section{AN AYURVEDIC CASE REPORT ON AMYOTROPHIC LATERAL SCLEROSIS}

\author{
Ambika. K' ${ }^{1}$ Arundhathi. K², Lekshmi G. Krishna ${ }^{3}$ \\ ${ }^{1}$ Professor \& HOD, Department of Kayachikitsa, Government Ayurveda College, Thiruvananthapuram, India \\ ${ }^{2}$ Final year PG Scholar, Department of Kayachikitsa, Government Ayurveda College, Thiruvananthapuram, India \\ ${ }^{3}$ Final year PG Scholar, Department of Kayachikitsa, Government Ayurveda College, Thiruvananthapuram, India
}

Corresponding Author: arundhathi.90@gmail.com

https://doi.org/10.46607/iamj4409112021

(Published Online: November 2021)

Open Access

C International Ayurvedic Medical Journal, India

Article Received: 06/11//2021 - Peer Reviewed: 12/11/2021 - Accepted for Publication: 15/11/2021

\section{Check for updates}

\section{ABSTRACT}

Amyotrophic Lateral Sclerosis (ALS) is a common and most severe type of Motor Neuron Disease. It is characterized by progressive skeletal muscle weakness, wasting and fasciculations. Survival is for 3-5 years, and the death is from respiratory paralysis. The incidence of ALS is between 0.6 and 3.8 per 100000 persons per year. Males are predominantly affected. Here is a case report of $45 \mathrm{yrs}$ old male who presented with complaints of difficulty in walking since 3years, with an insidious asymmetric onset of weakness of bilateral lower limbs with wasting and fasciculations. In Ayurveda, the case was symptomatologically diagnosed as Mamsa Sosha, which occurs as the result of obstruction of Snayu and Rakthadhamanis (Mamsavaha srotomoolas). The assessment was done using ALSFRS-R Scale. The treatment was aimed at improving the quality of life and also decreasing the rate of disease progression. The treatment principle adopted was Srothosodhana (Ama-Avaranaghna cikitsa) and Brimhana. Promising results were obtained after treatment.

Keywords: ALS, MND, Ayurveda, Avaranaghna cikitsa, Mamsa Sosha, Mamsa Kshaya

\section{INTRODUCTION}

Amyotrophic Lateral Sclerosis (ALS) is the most common form of progressive motor neuron disease, which is the most devastating of the neurodegenerative disorders. ${ }^{1}$ Average age of onset is 
45years in India. ${ }^{2}$ There is an incidence of $0.6-3.8$ per 100000 and a prevalence of 4.1-8.4 per $100000 .^{3}$ Males are more affected than females. The first evidence of the disease is insidiously developing asymmetric weakness, usually first evident distally in one of the limbs. The pathology is characterized by the loss of Pyramidal Betz cells in the motor cortex, as well as loss and degeneration of the large Anterior horn cells of the spinal cord and lower cranial motor nuclei of the brainstem. Weakness is associated with progressive wasting and atrophy of muscles, spontaneous twitching of motor units. When the denervation involves bulbar muscles, the symptoms are difficulty with chewing, swallowing and movement of face and tongue. Death is caused by the involvement of muscles of respiration.

Ayurveda being a medical science believes in symptomatologic diagnosis. Here the main symptom is Muscle wasting which can be correlated with Mamsa Sosha (wasting). Mamsa sosha is explained by Acharya Susrutha in the context of Mamsavaha Srotas. He opines that Moolasthana (root) of Mamsavaha srotas are Snayu, Twak (skin) and Rakthavahini dhamanis (circulation). Any Vidhathwa (injury/ obstruction) to these Moolasthanas lead to Svayathu (swelling), Soshana (wasting) and Siragrandhi (varicose veins). ${ }^{4}$ Here Snayu and raktavahini dhamanis are best correlated with neurological and vascular supply of muscle tissue respectively. Twak (skin), possibly due to its protective function.

Here Mamsa sosham manifested probably due to obstruction or injury to Snayu along with Rakta vahini dhamani, considering the neurological deficit in MND. Sosha indicates Vatavridhi. So, following Avaranagna, Mamsagata vata treatment protocol is best suited which includes Srothosodhana followed by Samana. ${ }^{5}$ Srothosodhana mainly includes Virechana (purgation) and Nirooha (enema) and Samana (pacification) for Vata dosha and Vata Pitta dosha is Brimhana (Nourishment) ${ }^{6}$ itself which includes Snehana. ${ }^{7}$ Snehana (unction) is indicated for nourishing Suskha dhathu ${ }^{8}$ and also repeated Sneha, Sweda (oleation and fomentation) is indicated in all
Vatavyadhi's. ${ }^{9}$ Association of Pitta along with Vata can lead to the immediate progression of the disease.

\section{Narrative}

A 45 years old male, known case of Type 2 Diabetes Mellitus for 5years, on irregular medication came to Hospital on 28/12/2020 with complaints of difficulty in walking, since 3years. He had insidious asymmetric onset of weakness of bilateral lower limbs (started distally) $(\mathrm{R}>\mathrm{L})$, wasting and fasciculations. He had high stepping gait on the right side and difficulty in negotiating chappals. There was no sensory, autonomic, bulbar symptoms or memory impairment. His father had similar complaints at the age of 70 and died at 75 years of age due to respiratory complaints.

On examination, the patient was anxious, alert and responding to vocal commands. The speech was clear. Muscle tone was hypotonic on bilateral lower limbs, Muscle bulk was reduced on bilateral lower limbs $(\mathrm{R}>\mathrm{L})$. Muscle power $5 / 5$ on bilateral upper limbs. Hip- abduction and adduction $5 / 5$ bilaterally, flexion and extension $4+/ 5$ bilaterally. At knees- flexion $4+/ 5$ bilaterally, extension $5 / 5$. At ankles- plantar flexion $5 / 5$ in left and $3 / 5$ on right. Dorsiflexion 5/5 bilaterally. Deep tendon reflexes were diminished on the left side and absent on the right side. Plantar reflexes were extensors bilaterally. Abdominal reflex was absent. There was a h/o trauma on the right knee 5 yrs back.

Haematological reports showed hyperglycemia and dyslipidemia. NCS (on 05/03-2019) showed prolonged distal latencies in the left peroneal nerve and reduced Compound Muscle Action Potential (CMAP) in bilateral peroneal and tibial nerves. EMG (on 19/11/2019) showed the proximal axonopathy process of lumbosacral segments.

The dietary pattern of the patient was irregular, preferred sweet and spicy food articles. Appetite and bowel were normal, had difficulty initiating sleep and was addicted to smoking.

\section{GENERAL EXAMINATION ON ADMISSION}

The patient came limping to OP, was conscious, alert, oriented, cooperative, moderately built and nourished, with erect posture. Afebrile, with pulse-76/min, regular rhythm, full volume. Respiratory rate- $16 / \mathrm{min}$, 
abdominothoracic. Blood pressure-110/70mmHg. On physical examination, asymmetrical thinning of muscles on $\mathrm{B} / \mathrm{L}$ lower limbs were noted. Involuntary fine twitching movements were present on the upper arm (R) and lower limbs. Findings of the Respiratory and Cardiovascular system were within normal limits, the abdomen was mildly distended and non-tender, bowel sounds were present, all cranial nerves were intact on examination. The sensory system was intact.

\section{DIAGNOSIS AND ASSESSMENT}

The patient was diagnosed by EI-Escorial criteria for MND/ALS by the World Federation of Neurology. The assessment was done before and after treatment using the Amyotrophic Lateral Sclerosis Functional Rating Scale-Revised (ALSFRS-R).

\section{ROGI- PAREEKSHA}

\section{Ashtasthana Pareeksha}

The Patient Nadi (pulse) was of Vata-Kapha. On examination, his Mutra (urine), Malam (stools) Jihwa (tongue), Sabda (sound), Sparsa (touch) and Drik (eyes) are found to be Sadharanam (normal).

\section{ROGA PAREEKSHA}

NIDANAS

1. Aharaja

Rasa - Madhura, Katu

Quantity - moderate

Quality - Seeta and Abhisyandi

\section{Viharaja}

Cigarette smoking

Prolonged standing

Hard work

Air Conditioning

Vata - Mutra - Pureesha Vegadharana

POORVARUPA - Avyaktam

LAKSHANA - Mamsa sosham, Gati sangam, Guru gatrata, Sphuranam

UPASAYA - Usna

ANUPASAYA - Seeta

SAMPRAPTI - Due to the prolonged use of cigarettes, Pitta Raktha dusti manifests, following that he started job in Saudi Arabia, there he developed Kaphaja prameha, by the intake Madhura, Abhisyandi Ahara and Seeta vihara due to constant A/C exposure. Kapha medodusti caused the defective formation of Snayu, especially in Adhakaya (lower body) due to prolonged standing along with that Pitta Rakta dusti vitiated the Raktavahini dhamini which together led to Mamsa Sosha. Here Vata dosha in Mamsa got obstructed (Avruta) by Pitta Kapha Dosha leading to Sthanika vatavridhi manifested as Mamsa Sosha.

\section{SAMPRAPTHI GHATAKAS}

Dushya: Dosha: Sannipatha

Dhatu: Rasa, Raktam, Mamsa, Medas

Upadhatu: Snayu

Agni: Madhyama

Srotas: Rasavaha, Rakthavaha, Mamsavaha and Medovaha

Srotodushti: Sangam

Rogamargam: Madhyama

Rogaswabhavam: Chirakari

Udbhava Sthana: Amasaya

Prasarasthana: Adhovaha dhamani

Asrayasthana: Snayu

Vyakthisthana: Adhakaya

Prakriti - Vata pitta

\section{CHIKITSA PRINCIPLE}

1. Nidana parivarjana (avoidance of causative and precipitating factors ) -

Avoiding Madhura, Abhisyandi Ahara, Sita Seva, prolonged standing and excessive work

2. Samprapti Vighatana Cikitsa (breaking the pathogenesis)

Ama Cikitsa (elimination of ama)

Avarana Cikitsa (removal of obstruction)

Mamsagata Vata Cikitsa (treatment for Vatadosha vitiation in Mamsadhatu)

3. Dhathusamyakara Cikitsa (Normalising tissues)

Treatment Done:

I. Amahara cikitsa

a. Deepana Pachana [D1 - D2]

1. Gandharvahastadi kashayam $-90 \mathrm{ml}$ Bd before food

2. Shaddharanam Tab $1 \mathrm{Bd}$ after food

b. Rookshana [D3 - D9]

1. Udwarthanam with Varachoornam

II. Avaranagna cikitsa

a. Pitta avarana cikitsa [D3 - D9]

1. Guloochyadi Kashayam $-90 \mathrm{ml}$ Bd before food

2. Vaiswanara choornam - 5g Bd with lukewarm 
water

\section{b. Kaphamedoavarana cikitsa [D10 - D16] Internal Treatment}

1. Nishakathakadi kasayam muhur muhur

2. Tab Goranchi $1 \mathrm{Bd}$ after food

External Treatment

1.Udgharshana - Jeevanthyadi choornam,

Dhanyamlam and Honey

c. Rajatamoavaranagna cikitsa

1. Manasamitravatakam $1 \mathrm{HS}$

III. Mamsagata Vata Cikitsa

a. Kayavirechana [D17-D29]

1. Snehana

Internal: Indukantham Ghritam $-10 \mathrm{~g}$ with Dhanwantharam Kasayam 90ml Bd before food

External: Abhyangam - Balatailam

Talam - Ksheerabala and Kachooradi choornam

2. Swedam

Choorna Pinda Sweda for 3 days

3. Virechana - Gandharveranda tailam - 20ml with milk morning 7 am

4. Peyadi kramam -2 days

b. Sirovirechana / Nasya [D30-D36]

1. Anutailam $-2.5 \mathrm{ml}$ each nostril for 3 days

2. Ksheerabala 7 Avarthi $-2.5 \mathrm{ml}$ each nostril for 4 days

Internal Medication -

- A decoction made of Guduchi, Satavari, Chandana and Bala 90ml Bd before food.

- Dhanwantharam sevya tailam - 5ml with kasayam

- Nishakathakadi kasayam -muhur

c. Nirooha [D37-D50]

Sneha sweda - Shashtika pinda sweda - 7days

Rajayapana Vasthi - 7 days

d. Samana chikitsa [D51-D71]

Internal treatment

Rasnadasamoola ghritam $5 \mathrm{ml} \quad \mathrm{Bd}$ with

Dasamoolaristam 30ml

External treatment

Pichu - Mahanarayana tailam on Rt lower limb -7 days

Adhakaya pizhinjutadaval - Mahamasha tailam - 7 days

Kativasti - Mahamasha tailam - 7 days

\section{Discharge Medicines:}

Rasnadasamoola ghritham 10g BD

Nishakathakadi kasayam -muhur

A decoction made of guduchi, satavari, chandana and bala $-90 \mathrm{ml} \mathrm{Bd}$

\section{RESULTS}

After the treatment for $2^{1} / 2$ months, the patient's walking improved, negotiation of chappals were possible, weakness of the lower limbs improved with a marked reduction in the frequency of fasciculations. During the hospital stay, no progression of the disease was noted. The ALSFRS-R score was 46 before the treatment which became 52 after the treatment.

\section{DISCUSSION}

MND is a progressive neurodegenerative disorder that affects both the upper and lower motor neurons. In Ayurveda, as the pathology starts with Ama formation due to Apathya ahara- vihara (unwholesome regimen), treatment starts with Deepana Pachana (appetizer and digestant) using Gandharvahasthadi Kashayam which is mentioned as Deepana, Anulomana oushada in the context of Vatavyadhi (Sahasrayogam). Shaddharana choornam is Deepana Pachana indicated in Amasaya gata vata.

After Deepana Pachana, Avaranagna Chikitsa is the next step required for which Rookshana can be done externally by Udwarthana with Varachoornam. Pitta Avarana Chikitsa given prior importance in Kapha Pitta Avarana. So Guloochyadi kasayam is given as Pitta Kapha Samana and in order to improve Agnibala, Vaiswanara Choornam is added. The next stage is Kaphamedo Avaranagna, Udgharshana having the property of Kapha Medoharatva is given, whereas medicines Jeevanthyadi Choornam, Dhanyamlam and honey alleviate the associated pitta dosha also. Pramehagna oushadas like Nishakathakadi and Goranchi are given considering the Pitta Dosha. Goranchi contains Silajathu as one of the main ingredients, having Chedya property. As The patient also experiences stress and sleeplessness, Manasamitravatakam is also added.

After giving Avaranagna Chikitsa, the next Dosha to be considered is the Avrutha Vata, as it is the main 
culprit of Kshaya. As the pathology occurs in Mamsa Dhatu, Mamsa Gata Vata protocol can be adopted, which includes Virechana, Nirooha and Dosha samana. Virechana is done following Sneha Sweda. Snehana is done with Indukantham ghritam, which is given along with Dhanwantharam Kasayam, where Indhukantham ghritam is having the property of Deepana Pachana and its initial indication is Vatavyadhi and Dhanwantharam Kasayam is Vata Pitta Samana, Brimhana Yoga which is suitable for the Dosha Samanatva and Dhatu Poshana of previous traumatic condition. Virechana is given using Gandharverandam in milk after Choorna Pinda Sweda, as a combination of Eranda Tailam (castor oil) and milk is indicated for Sodhana in Vatavyadhi. Following Kayavirechana, Sirovirechana is done first three days with Anutailam and the following four days with Ksheerabala Tailam 7 Avarthi. A decoction made of Guduchi, Satavari, Chandana and Bala is given, which is mentioned in cikitsa manjari, as it is Vatapittahara and Balya. After Virechana, Rajayapanavasti ${ }^{10}$ is given following Shashtikapinda Sweda which is at same time Srotosodhana and Balya. The final protocol is Dosha Samanatva which is Brimhana for Vata and Vata-Pitta and is given as Pichu, Pizhinjutadaval and Kativasti. Pichu is given with Mahanarayana Tailam, as it is indicated in Snayu Roga and Karshitha for the purpose of Brimhana. ${ }^{11}$ Pizhinjutadaval and Kativasthi are done with Mahamashatailam, a Brimhana Yoga which is indicated in Mandha Chankrama (difficulty walking) in Bhaishajya ratnavali Vatavyadhi chapter. Rasnadasamoolaghrita mentioned in Kasa Chikitsa of Astangahridaya is given as Brimhana Sneha as it contains Ajamamsa which can bring Dhathu Samyavastha (normalcy of dhatus).

\section{CONCLUSION}

Motor neuron disease is a progressive condition where muscle wasting is the predominant symptom. As a science rooted in symptomatology, Ayurveda focuses on symptomatologic diagnosis which is Mamsa sosha. It is very well explained by Acharya Susrutha in Vidha lakshanas of Moolasthana of Mamsavaha Srotas, Snayu and Rakthavahini Dhamanis. Vidha can be understood as the obstruction by Kapha and Pitta Doshas. So Avaranahgna chikitsa was done, followed by Mamsagata Vata Chikitsa for vitiated Vata Dosha, which ultimately caused Mamsa Sosha.

\section{REFERENCES}

1. Jameson J, Kasper D, Longo D, Fauci A, Hauser S, Loscalzo J. Harrison's Principles of Internal Medicine. 17th Ed. United States of America: The Mcgraw Hill Companies; 2008. p. 2572.

2. Das K. Textbook of Medicine. 5th Ed. New Delhi: Jaypee Brothers Medical Publishers (P) Ltd; 2008. p. 1296.

3. Longinetti E, Fang F. Epidemiology of Amyotrophic Lateral Sclerosis: An Update of Recent Literature. Current Opinion in Neurology. 2019;32(5):771-776.

4. Murthy, K., 2010. Illustrated Susruta Samhita Sarirasthana. Varanasi: Chaukhamba Orientalia, p.149.

5. Murthy K. Vagbhata's Astanga Hrdayam Cikitsasthana. Varanasi: Chowkhamba Krishnadas Academy; 2003. p. 500.

6. Murthy K. Vagbhata's Astanga Hrdayam Sutrasthana. Varanasi: Chowkhamba Krishnadas Academy; 2008. p. 193.

7. Murthy K. Vagbhata's Astanga Hrdayam Sutrasthana. Varanasi: Chowkhamba Krishnadas Academy; 2008. p. 192.

8. Murthy K. Vagbhata's Astanga Hrdayam Cikitsasthana. Varanasi: Chowkhamba Krishnadas Academy; 2003. p. 498.

9. Murthy K. Vagbhata's Astanga Hrdayam Cikitsasthana. Varanasi: Chowkhamba Krishnadas Academy; 2003. p. 498.

10. Murthy, K., 2010. Illustrated Susruta Samhita Cikitsasthana. Varanasi: Chaukhamba Orientalia, p.380.

11. Rao G. Bhaishajya Ratnavali II. Varanasi: Chaukhamba Orientalia; 2014. p.188. 


\section{Attachments}

ALS Functional Rating Scale-Revised (ALSFRS- R)

\begin{tabular}{|l|l|c|c|}
\hline Sl. No & FUNCTION & BEFORE TREATMENT & AFTER TREATMENT \\
\hline 1 & Speech & 4 & 4 \\
\hline 2 & Salivation & 4 & 4 \\
\hline 3 & Swallowing & 4 & 4 \\
\hline 4 & Handwriting & 4 & 4 \\
\hline $5 a$ & Cutting Food \& Handling Utensils & 4 & 4 \\
\hline $5 b$ & Cutting Food \& Handling Utensils & 4 & 4 \\
\hline 6 & Dressing and Hygiene & 4 & 4 \\
\hline 7 & Turning in Bed and Adjusting Bed Clothes & 3 & 4 \\
\hline 8 & Walking & 3 & 4 \\
\hline 9 & Climbing Stairs & 1 & 3 \\
\hline 10 & Dyspnea & 3 & 4 \\
\hline 11 & Orthopnea & 4 & 4 \\
\hline 12 & Respiratory Insufficiency & 4 & 4 \\
\hline & TOTAL & $\mathbf{4 6}$ & \\
\hline
\end{tabular}

\section{Source of Support: Nil}

\section{Conflict of Interest: None Declared}

How to cite this URL: Arundhathi. K et al: An Ayurvedic Case Report On Amyotrophic Lateral Sclerosis. International Ayurvedic Medical Journal \{online\} 2021 \{cited November 2021\} Available from: http://www.iamj.in/posts/images/upload/2903_2908.pdf 